\title{
Article \\ The Effect of On-the-Job Training and Education Level of Employees on Innovation in Emerging Markets
}

\author{
Kyunga $\mathrm{Na}$
}

\section{check for}

updates

Citation: Na, K. The Effect of On-the-Job Training and Education Level of Employees on Innovation in Emerging Markets. J. Open Innov. Technol. Mark. Complex. 2021, 7, 47. https://doi.org/10.3390/joitmc 7010047

Received: 1 January 2021

Accepted: 25 January 2021

Published: 27 January 2021

Publisher's Note: MDPI stays neutral with regard to jurisdictional claims in published maps and institutional affiliations.

Copyright: (C) 2021 by the author. Licensee MDPI, Basel, Switzerland. This article is an open access article distributed under the terms and conditions of the Creative Commons Attribution (CC BY) license (https:/ / creativecommons.org/licenses/by/ $4.0 /)$.
Department of International Business, College of Business, Chungbuk National University, Cheongju 28644, Korea; kna@chungbuk.ac.kr

\begin{abstract}
This study investigates the effects of on-the-job training and education level of employees on innovation in emerging markets using sample firms from BEEPS 2013 (Business Environment and Enterprise Performance Survey 2013) datasets provided by the World Bank. The Heckman two-stage regression model is used in order to control for endogeneity over a final sample of 10,366 firms in Eastern Europe and Central Asia. To estimate innovation of firms, five indicators of innovation (product, process, organizational, marketing innovation, and R\&D investments) are considered. The results of the study suggest that both on-the-job training and education level of employees have significant and positive impact on all forms of innovation. This finding implies that firms in Eastern European and Central Asian emerging markets can promote innovation by offering more on-the-job training programs or recruiting more educated employees.
\end{abstract}

Keywords: innovation; on-the-job training; education level of employees; BEEPS 2013; emerging markets

\section{Introduction}

This study examines the relations between innovation of a firm and its human capital factors, such as on-the-job training and education level of employees. Since innovation is important for a firm's survival and sustainable economic growth [1], innovation is often researched for firms in both developed countries and emerging markets. Anecdotal studies, like Dawar and Frost [2], show how innovation has helped firms in emerging markets succeed in rapidly globalizing market, while empirical studies, like Atalay et al. [3], demonstrate that innovation has a positive relation with firm performance in emerging markets.

Vast literature focuses on the factors that influence innovation. In general, firm characteristics, such as strong external financing, competition with foreign firms, high education level of manager, and R\&D (Research and Development) activities, have been repeatedly shown to lead to innovation [4,5]. Gender diversity has shown mixed results, as gender influences innovation differently based on the position in the firm, ranging from board of directors to employees. Social, economic, and political background of the firm also provide mixed results. For instance, Zhou et al. [6] argue that, in China, minority state ownership makes firms in the manufacturing industry the most innovative. Mahmood and Mitchell [7] report that business groups in emerging markets can both promote and hinder innovation.

An important determinant of innovation is human capital. Based on the resourcebased view of a firm, greater human capital provides more resources to a firm and therefore should lead to more innovation. Education level and on-the-job training are frequently researched aspects of human capital. Higher level of education would make more knowledge available to the firm and therefore greater innovation. Arvanitis and Stucki [8] demonstrate that one of the aspects influencing innovation in start-ups is the education level of the founders. Marvel and Lumpin [9] state that, while greater education, experience, and knowledge on the product or the technology improves innovation, more knowledge on the actual delivery of the product hinders innovation. In contrast, on-the-job training would provide skills and knowledge that is relevant to the occupation, increasing the likelihood of 
innovation. A number of papers show that there is a positive relation between on-the-job training and innovation in both developed and emerging markets [10-12].

One of the issues with the current literature is that, while training has been shown consistently to have positive influence on innovation, the results are mixed for education level in emerging economies. This makes it important to update the results, particularly for education level, based on changes in the economy. This paper attempts to perform this task by providing an updated relationship in Eastern Europe and Central Asia between education level, on-the-job training, and an expanded set of innovation using the most up-to-date dataset.

In the previous literature, Nazarov and Akhmedjonov [13] have addressed this research question based on data from BEEPS (Business Environment and Enterprise Performance Survey) provided by WBES (World Bank Enterprise Survey [14]). However, their analysis has some limitations. First, Nazarov and Akhmedjonov [13] use BEEPS II (BEEPS 2002) and BEEPS III (BEEPS 2005) where the survey questionnaire on innovation is focused only on product innovation. To mitigate this limitation, Nazarov and Akhmedjonov [13] include two additional factors-product-licensing agreements and quality accreditationsas a part of innovation. Second, the business environments of firms in Eastern Europe and Central Asia have changed significantly after 2005. As most countries in Eastern Europe and Central Asia joined the EU around 2005, it is likely that any short-term effect of joining the EU have decayed. These countries also have become more stabilized in terms of economy and business environment since 2005 [15]. Furthermore, the 2008-2009 Financial Crisis has caused a drastic change in the global economy. Consequently, it seems likely that the relation among innovation, education level, and on-the-job training has changed with the most up-to-date data.

To reflect these changes, this study investigates the effect of education level of employees and on-the-job training on innovation in emerging markets using the BEEPS 2013 (BEEPS V), which broadens the definition of innovation to include not only product innovation (introduction of new or improved products or service) but also process innovation (introduction of new methods in production or service), organizational innovation (introduction of new organizational structure), marketing innovation (introduction of new marketing methods), and investment in R\&D activities (R\&D investment). In addition, the study considers not only the percentage of employees with university degree to proxy for the quality of education but also the average number of years for education of employees as a proxy for the quantity of education level. To control for endogenous problems caused by sample selection bias, i.e., a firm's selection of providing on-the-job-training or recruiting higher educated people, can be affected by firm characteristics, this research utilizes the Heckman two-stage regression model [16].

\section{Literature Review}

\subsection{The Importance of Innovation in Emerging Markets}

Innovation is widely accepted as one of the driving forces behind business productivity and sustainable economic growth (Beaver and Jennings [17], Bourke and Crowley [18], Romer [19]). According to Schroeder et al. [20], innovation can be defined as "the development and implementation of a new idea". This "new idea" is not limited to simply new products or technology but also includes new production processes, organizational structure and marketing (Atalay et al. [3]).

Past literature has shown that, regardless of its form, innovation enhances firm performance (Danneels [21], Hult et al. [22], Kleinschmidt and Cooper [23], Camison and Lopez [24], Varis and Littunen [25], Ar and Baki [26], Morone and Testa [27], Vivero [28], Rosenberg [29], Diaz-Fernandez et al. [30], Laplagne and Bensted [31]). This evidence makes innovation especially crucial for firms in emerging markets since firms in emerging economies tend to have limited access to other resources for achieving growth. Several papers provide anecdotal evidence that supports the importance of innovation for firms in emerging markets. For example, Dawar and Frost [2] perform a case study of firms in 
emerging markets that have survived against multinational corporations and find that all survivors have innovated in some way; whether it is realigning existing assets to reinforce their positions in market segments where multinationals are weak; moving to a different position in the value chain; extending assets to similar markets abroad; or upgrading their capabilities to rival the foreign competitors in the global market. Krishnan and Jha [32] study five Indian firms that have become market leaders after deregulation. They claim that those firms could become market leaders by either adopting the existing capacities to suit the rapidly changing markets, or by exploring new paths and quickly exploiting the results. Empirical research supports the anecdotal evidence. Atalay et al. [3] investigate the Turkish automotive supplier industry and report that product and process innovation has significant impact on firm performance. Hu et al. [33] analyze the effect of different types of innovation on the performance of firms in hotel industry in Ghana and find that process, product, marketing, and organizational innovation all have positive influence on firm performance. Kurt and Kurt [34] show that innovation improves labor productivity for firms in Brazil, Russia, India, and China (BRICs). Rajapathirana and Hui [35] investigate the relationship between the type of innovation and performance of insurance firms in Sri Lanka, reporting that innovation other than organizational innovation are positively associated with firm performance. Lynch and Jin [36] find that both non-technical and technical innovations are necessary for Chinese automobiles industry to meet the global standards.

\subsection{Determinants of Innovation}

Given such evidence from past literature, it is imperative for firms in emerging markets to innovate. The question that naturally follows is 'how to achieve innovation'. One of the key streams in innovation research is the identification of the determinants of innovation. There is a plethora of research that provides possible determinants of innovation (McGrath et al. [37], Varis and Littunen [25], Cho and Pucik [38], Santamaria et al. [39], Reuvers et al. [40], Yun and Liu [41], Yun et al. [42], Yun et al. [43]). For example, Ayyagari et al. [4] provide a comprehensive list of firm characteristics that can influence innovation, including firm age; size; export vs. importing firm; ownership structure; manager education and experience; competition; technology level; and access to external financing. Gorodnichenko et al. [5] find that greater foreign competition leads to more innovation in emerging economies regardless of sector. Zhou et al. [6], who investigate the effect of state ownership on innovation of firms in China, show that, while state ownership gives firms access to crucial R\&D resources, it also makes firms less efficient in using the resources to generate innovation. This inefficiency is found to decrease for start-ups and firms with high competition. Wang and Kafouros [44], who also look at firms in China, report that foreign direct investment (FDI) and international trade improve innovation.

$\mathrm{R} \& \mathrm{D}$ is a driving factor that is frequently investigated in past literature. Wang and Kafouros [44] find that, while FDI and international trade improve innovation, internal R\&D has a much greater impact on innovation. Reichstein and Salter [45] show that presence of formal R\&D enhances process innovation for UK manufacturing firms. Gonzalez et al. [12] find a similar result for Spanish firms, where R\&D not only increases the probability of product and process innovation but also the actual number of innovation that are introduced. Ar and Baki [26] report that, among a number of factors, R\&D has a significantly positive impact on product innovation.

Another important factor of innovation is gender diversity at various levels of the firm, ranging from the board of directors and the top manager to non-managerial employees. The results for gender diversity are mixed. Some papers find female top managers can reduce innovation (Schøtt and Cherghi [46], Ayub et al. [47], Mueller [48]). Others find gender diversity to improve innovation. Chen et al. [49] find that greater representation of female directors lead to more R\&D investment and innovative success. Na and Shin [50] show that female ownership is positively related to various types of innovation in emerging markets; female top manager is positively associated with marketing innovation only; and female majority in the workforce is not related to any innovation. Turner [51] finds that 
gender diversity improves innovative performance of teams and individuals for firms in Europe. Østergaard et al. [52] report that gender diversity improves innovation likelihood in Danish firms. Galia et al. [53] find that board gender diversity leads to greater probability of environmental innovation in French firms.

The social, economic, and political backdrop of the firm and its workforce also influence innovation. Chang et al. [54] and Mahmood and Mitchell [7] both look at the effect of business group affiliation on innovation of firms in South Korea and Taiwan. Chang et al. [54] find that affiliates were more innovative than independent firms in Korea than in Taiwan, but the benefits decline with infrastructure for innovation. They also find that, for Korea, group-level financial and technological resources help affiliates with insufficient resources to innovate. Similarly, Mahmood and Mitchell [7] report that business groups initially foster innovation by providing the necessary infrastructure, but inhibits it later by creating entry barriers. The trade-off is dependent on the available market infrastructure for innovation. Li [55] investigates the effect of investment in political ties, such as bribes, on innovation and productivity in transition economies, reporting that, while bribery has no influence on product or organizational innovation, the managerial time spent on political ties weakens the relations between organizational innovation and productivity. Kushinirovich and Heilbrunn [56] find that the immigration background affects the entrepreneurial drive among high-tech workers in Israel. Ozgen et al. [57] look at Dutch firms, and show that simply having more foreign workers can reduce innovation; instead, having greater diversity of foreign workers is shown to have a positive impact on product and process innovation. Østergaard et al. [52] find that, in addition to gender, education diversity also improves innovation likelihood, while age diversity reduces the likelihood. Galia et al. [53] also report that board age diversity leads to greater intensity of environmental innovation, but that greater proportion of employee directors harm environmental innovation.

\subsection{Human Capital and Innovation}

A key driver of innovation is human capital. Barney [58] claims that a firm's core competencies are supported by its strategic resources. Strategic resources can be divided into (a) tangible resources, such as raw materials and production facilities, and (b) intangible resources, such as know-how, skills, and brand. Human capital, the aggregate of skills and resources available to the individuals in a firm, is a source of intangible resources of a firm. This resource-based view of a firm implies that human capital is a key determinant of innovation, which is supported by previous research, such as Andries and Czarnitzki [59], who report that small firms in Germany tend to underutilize non-CEO(Chief Executive Officer) ideas, and that using non-CEO ideas improve innovation performance.

There are several ways for a firm to improve its human capital. One method is increasing the diversity of the employees, which may explain the previous papers on gender and cultural diversity. Another two important methods that are often discussed in the past literature are formal education and on-the-job training. Many papers attempt to identify the relationship between formal education, training, and innovation. On the one hand, training is shown to positively affect innovation. Abdullah et al. [10] find that, for SMEs(Small and medium-sized enterprises) in Malaysia, training is one of the significant predictors of innovativeness. Bauernschuster et al. [11] look at firms in Germany and find that a firm's investment in continuous training raises the firm's probability of innovation. Børing [60] analyzes Norwegian enterprises and reports that training has a significant impact on open innovation. Diaz-Fernandez et al. [30] show that, for Spanish manufacturing firms, investment in specific skills training enhances innovation. Gallie and Legros [61] show that greater investment in employee training leads to more innovation in French firms. Goedhuys [62] show that, in least-developed countries, like Tanzania, local SMEs innovate through collaboration with foreign firms rather than training, while foreign firms innovate through training. Gonzalez et al. [12] find that training boosts innovation even in the absence of $R \& D$ and that it marginally reinforces the effect of R\&D in larger 
firms. Khatiwada and Arao [63] look at a large number of firms in emerging markets, and find that training positively influences innovation. De Winne and Sels [64] look at Belgian start-ups and show that owners' human capital, employee human capital, and HR practices, such as training, can contribute to innovation. This discussion leads to the first hypothesis of this study:

Hypothesis 1. On-the-job training is likely to increase the innovation activities of a firm.

On the other hand, the evidence for formal education is less clear. While education generally seems to affect innovation, the effect is usually marginally positive compared to training or, in some cases, even negative. Arvantis and Stucki [8] show that startup founding teams with university degrees tend to be more innovative. Marvel and Lumpkin [9] show that among a number of factors, formal education positively affects radical innovation. D'Amore et al. [65] find that having more graduated employees lead to higher product turnover, and that the marginal returns for human capital decreases with increasing human capital. Zhang et al. [66] find that higher education level of employees amplifies the effect of innovation. Khatiwada and Arao [63] show that, while education positively influences innovation, the effect is small compared to that of training. Pan et al. [67] look at the effect of higher education on firm innovation in China. They find that number of higher education institutions decrease province-level innovation, but the number of "elite" higher education institutions under direct control of the central government has a positive effect. They argue that this gap occurs because China has focused too much on expanding the quantity, rather than raising the quality, of higher education graduates. Van Uden et al. [68] research sub-Saharan countries and find that human capital practices, like training, have a much more significant effect than traditional factors, like education on innovation. Employee education actually has a marginally negative effect on innovation for manufacturing firms. Nazarov and Akhmedjonov [13] show that, for Eastern European firms, education has no significant influence on innovation, while training has significantly positive effect. Based on this notion, we cannot give a clear direction for the effect of education. However, given the implications of the resource-based view of human capital, it seems more likely that greater formal education would lead to greater innovation. This leads to the second hypothesis of this study:

Hypothesis 2. Greater formal education is likely to increase the innovation activities of a firm.

\section{Research Method}

\subsection{Data and Sample}

To examine the hypotheses of this study, sample firms are collected from the BEEPS 2013 of the World Bank Enterprise Survey (WBES). The World Bank and the European Bank for Reconstruction and Development (EBRD) have jointly conducted a survey regarding business environment and firm performance on Eastern European and Central Asian countries over five rounds $(1999,2002,2005,2009$, and 2012-2014) and have created five datasets that contain firm-level information, such as general information (size, industry, region, ownership structure, etc.), infrastructure, sales and costs, competition, innovation, capacity, crime, finance, business-government relations, labor, business environment, performance, expectation, etc. (BEEPS I, BEEPS II, BEEPS III, BEEPS IV, and BEEPS V, respectively [69]. Among those five datasets, the BEEPS 2013 (also known as BEEPS V) is the most recent.

The original sample consists of 15,883 firms. However, 5517 observations are eliminated from the final sample since they do not have both instrument variables ( $\%$ of GDP of government spending in education, and \% of labor force with advanced education in total working-age population) in the World Development Indicators metadata of the World Bank [70], leaving 10,366 firms as the final sample with all necessary variables. Sample characteristics by industry, size, and firm type are presented in Table 1. While about $41 \%$ of sample firms belong to wholesale and retail industry, $34 \%$ and $25 \%$ come from 
manufacturing and service and other industry, respectively. For firm size, $2.48 \%, 54.68 \%$, $31.3 \%$, and $11.54 \%$ of sample firms are identified as micro size, small size, medium size, and large size firms, respectively. For ownership structure, $0.33 \%, 92.12 \%$, and 5.09\% of firms are those whose majority shareholder(s) is (are) government, domestic owner(s), and foreign owner(s). About $92 \%$ of firms are corporation, and $4.85 \%$ of sample firms consist of multiple establishments.

Table 1. Characteristics of sample.

\begin{tabular}{ccc}
\hline & Panel A: Industry & \\
\hline Industry & Firms & \% \\
\hline Manufacturing & 3530 & 34.05 \\
Wholesale and Retail & 4210 & 40.61 \\
Service and Other & 2626 & 25.33 \\
\hline Total & 10,366 & 100.00 \\
\hline & Panel B: Size & \\
\hline Size & Firms & $\%$ \\
\hline Micro (total employees $<5)$ & 257 & 2.48 \\
Small (5 $\leq$ total employees $\leq 19)$ & 5668 & 54.68 \\
Medium (20 $\leq$ total employees $\leq$ 99) & 3245 & 31.30 \\
Large (total employees $\geq 100)$ & 1196 & 11.54 \\
\hline Total & 10,366 & 100.00 \\
\hline Type & Panel C: Firm Type & $\%$ \\
\hline State Ownership & Firms & 0.33 \\
Domestic Ownership & 34 & 92.12 \\
Foreign Ownership & 9549 & 5.09 \\
Corporation & 528 & 91.76 \\
Multiple Establishments & 9512 & 4.85 \\
\hline Total & 503 & 100.00 \\
\hline
\end{tabular}

\subsection{Research Model}

The objective of this study is to test how human capital affects innovation of a firm. However, a firm's selection to hire more educated employees or to provide on-the-jobtraining can be affected by firm characteristics, which may cause endogenous problem from sample selection bias. There are several ways to mitigate concerns of endogeniety in economics and finance field. Li [71] examines commonly used econometric methods which address endogeneous problem in exploring the relation between CEO power and firm performance, and finds that the order of correction effect on endogeneity concerns is GMM (Gaussian Mixture Model), instrumental variables, fixed effect models, lagged dependent variables, and use of more control variables. In addition, Li [71] reveals that firm or year fixed effects, and the use of more useful control variables can be effective to mitigate endogenous problem even if no valid instrumental variables are used. On the other hand, the Heckman two-stage model is often used for correcting sample selection bias [16,72,73]. This study adopts the latter since it is effective to control for sample selection bias, as well as problems caused by omitted variables [16].

\subsubsection{First Stage Regression Model}

A probit regression, shown in Equation (1), is constructed in the first stage. In Equation (1), the dependent variable is an indicator variable which represents each of the three variables related to human capital (Human capital), while explanatory variables are composed of two instrumental variables (Instrument) and control variables (Control). Since the regression is performed for each indicator variable, three probit regressions are run in total. 
The Inverse Mills Ratio (IMR) is calculated in each probit regression and inserted in the second stage regression as a control variable.

$$
\text { Human capital }=\alpha+\beta_{i} \text { Instrument }+\Sigma \text { Control }+\varepsilon_{i} .
$$

Specifically, the dependent variable in Equation (1) is each of the following three indicator variables related to human capital of a firm: OJT (equal to 1 if a firm has formal training program for its permanent, full-time workers, and 0 otherwise), Edu_high (equal to 1 if average number of years of education of typical production worker is greater than 12 , and 0 otherwise), and Univ_high (equal to 1 if \% of permanent full-time workers with a university degree is greater than $50 \%$, and 0 otherwise).

The instrumental variables in Equation (1) are GDP_edu (\% of GDP of government spending in education) and Labor Force_adv (\% of labor force with advanced education in total working-age population). Across the three separate regression models in the first stage, robust standard errors are used in order to control for heteroscedasticity and firm clustering effects (Petersen [74]).

To control for confounding effects, the following control variables are included in Equation (1). Firstly, firm size is a widely used control variable as a firm characteristics known to affect firm decisions in financing, operating, and investing activities. To measure firm size, various proxies are utilized, such as total assets, total sales, or market capitalization, as well as the number of employees. Although these measures usually share similar direction and significance, they reflect different aspects of firm size and thus affect other variables and the fitness of the model $\left(\mathrm{R}^{2}\right)$ differently (Dang et al. [75]). Thus, it is necessary to check the robustness of firm size measures. Since BEEPS 2013 provides total sales and the firm size based on number of employees separately, I use firm size as a log of total sales in the main research design and further check the robustness in the sensitivity test by using the number of employees (Large size: 100+ employees, Medium size: $20 \leq$ employees $\leq 99$, Small size: $5 \leq$ employees $\leq 19$, and Micro size: employees $<5$ ) as a control variable. Since a firm's innovation is likely to be influenced by ownership structure (Ayyagari et al. [4]), the following variables are included as control variables: State_ownership (1 if the government's ownership $>50 \%$, and 0 otherwise), Domestic_ownership ( 1 if the domestic shareholders' ownership $>50 \%$, and 0 otherwise), and Foreign_ownership (1 if the foreign shareholders' ownership $>50 \%$, and 0 otherwise). Unobservable characteristics of CEO (or manager) can produce biased estimates, perhaps causing the endogeneity problem $[76,77]$. To control for this problem, this study uses the Heckman two-stage model, as well as CEO tenure (Log_CEO_experience: natural logarithm of the number of years the CEO has worked for) and CEO gender (CEO_female: 1 if the CEO of a firm is female, and 0 otherwise), as control variables. In addition, other control variables used in Ayyagari et al. [4] are also included: Log_firm age (natural logarithm of firm age), Corporation (1 if a firm is a corporation, and 0 otherwise), Multiple_establishments (1 for a firm with multiple establishments, and 0 otherwise), Capacity (\% of capacity utilization devided by 100), External_financing (\% of external financing devided by 100), Log_competitors (natural logarithm of the number of competitors), Sales_domestic (\% of domestic sales divided by 100), and Industry_Dummy (dummies for industry: manufacturing, wholesale and retail, service and other). In the first stage regression model, country dummies are not included since instrumental variables (GDP_edu or Labor Force_adv) work as country dummies.

\subsubsection{Second Stage Regression Model (Main Regression Model)}

The main regression of this study is the probit regression shown in Equation (2). The dependent variable is each of the five innovation measures, while the test variable is each of the three human capital related measures (OJT, Edu_high, and Univ_high) described in Equation (1). Similar to Equation (1), a set of control variables is included in Equation (2). 
Since a regression is performed for each combination of innovation and human capital measures, 15 regressions are used in total.

$$
\text { Innovation }=\alpha+\beta_{i} \text { Human capital }+\Sigma \text { Control }+\varepsilon_{i} \text {. }
$$

The dependent variable of the main regression is each of five innovation measures estimated by five innovation indicator variables (Product_inno, Process_inno, Organizational_inno, Marketing_inno, RED_investment) shown in Panel A of Table 2. In the original survey, 8 questionnaires are given. However, three questionnaires are not considered in this study because the second questionnaire is directly derived from the first questionnaire (whether the new products or service in the first questionnaire were first to the market), while the last two questionnaires do not apply Russia. Compared to BEEPS II and III, which focus on product innovation, BEEPS V extends the definition of innovation to include product (new or significantly improved products or service), process (new or significantly improved methods in production or service), organizational (new or significantly improved organizational/management practices/structure), and marketing innovation (new or significantly improved marketing methods), as well as R\&D investment (spending on R\&D activities), during the last three years. This set expands the coverage of innovation over Nazarov and Akhmedjonov [13] (from BEEPS II and BEEPS III), who use (1) upgraded existing product line/service, (2) obtained a new product-licensing agreement, and (3) obtained a new quality accreditation. For each innovation activity, an indicator variable is constructed in the following way; one if a firm achieves relevant innovation during the last three years of a firm, and zero otherwise. Based on Panel B of Table 2, 26.70\%, $22.12 \%, 22.95 \%$, and $24.83 \%$ of sample firms introduce new or improved product, process, organizational structure, and marketing methods, while $11.35 \%$ of firms invest in R\&D activities during the last three years.

Table 2. Dependent variable of main regression.

\begin{tabular}{ccc}
\hline & Panel A: Measure of Innovation \\
\hline Measure & Definition \\
\hline Product_inno & 1 for achieving product innovation during the last three years, \\
and 0 otherwise
\end{tabular}

The test variable of the second stage regression is each of three human capital measures (OJT, Edu_high, and Univ_high, respectively) described in Equation (1) (see Panel A of Table 3). Around $40 \%$ of firms have on-the-job training for permanent, full time workers, while $9.29 \%$ have typical production workers whose average number of years of education is greater than 12 . 
Lastly, $34.5 \%$ of firms have at least $50 \%$ of permanent full-time workers with a university degree (see Panel B of Table 3).

Table 3. Test variable of main regression.

\begin{tabular}{|c|c|c|}
\hline \multicolumn{3}{|c|}{ Panel A: Measure of Human Capital } \\
\hline Measure & \multicolumn{2}{|c|}{ Definition } \\
\hline OJT & \multicolumn{2}{|c|}{$\begin{array}{l}1 \text { for a firm with a formal job training program } \\
\text { for permanent, full-time workers, and } 0 \text { otherwise }\end{array}$} \\
\hline Edu_high & \multicolumn{2}{|c|}{$\begin{array}{l}1 \text { for a firm with the average length of education for typical } \\
\text { production worker }>12 \text { years, and } 0 \text { otherwise }\end{array}$} \\
\hline Univ_high & \multicolumn{2}{|c|}{$\begin{array}{l}1 \text { for a firm with permanent full-time workers } \\
\text { with a university degree } \geq 50 \% \text {, and } 0 \text { otherwise }\end{array}$} \\
\hline \multicolumn{3}{|c|}{ Panel B: Distribution of Human Capital } \\
\hline Measure & Frequency & $\%$ \\
\hline OJT & 4106 & 39.61 \\
\hline Edu_high & 963 & 9.29 \\
\hline Univ_high & 3576 & 34.50 \\
\hline
\end{tabular}

For control variables, country dummies and Inverse Mills Ratio (IMR) are added to the set of control variables used in Equation (1). Similar to the first stage, robust standard errors are used in all regression models in the second stage (Petersen [74]).

\section{Empirical Results}

\subsection{Descriptive Statistics}

Table 4 provides the mean and standard deviation of each variable. For dependent variables of the main regression, the mean is 0.27 (standard deviation $=0.44$ ) for product innovation, 0.22 (standard deviation $=0.42$ ) for process innovation, 0.23 (standard deviation $=0.42$ ) for organizational innovation, 0.25 (standard deviation $=0.43$ ) for marketing innovation, and 0.11 (standard deviation $=0.32$ ) for R\&D investment. For the test variables of the main regression, the mean is 0.4 (standard deviation $=0.49$ ) for OJT, 0.09 (standard deviation = 0.29) for Edu_high, and 0.34 (standard deviation = 0.48) for Univ_high.

Table 4 also reports the correlation matrix between variables except for industry and country dummies. The five innovation measures are highly correlated each other at the $1 \%$ level. While test variable OJT and Edu_high are significantly associated with all innovation measures, Univ_high is correlated with only organizational innovation and marketing innovation at the conventional level. 
Table 4. Descriptive statistics ( $\mathrm{N}=10,366)$.

\begin{tabular}{|c|c|c|c|c|c|c|c|c|c|c|c|c|c|c|}
\hline No. & Variable & Mean & SD & 1 & 2 & 3 & 4 & 5 & 6 & 7 & 8 & 9 & 10 & 11 \\
\hline 1. & Product_inno & 0.27 & 0.44 & 1.00 & & & & & & & & & & \\
\hline 2. & Process_inno & 0.22 & 0.42 & $0.48^{* * *}$ & 1.00 & & & & & & & & & \\
\hline 3. & Organiation_inno & 0.23 & 0.42 & $0.36^{* * *}$ & $0.48^{* * *}$ & 1.00 & & & & & & & & \\
\hline 5. & RED_spending & 0.11 & 0.32 & $0.32^{* * *}$ & $0.32^{* * *}$ & $0.32^{* * *}$ & $0.29^{* * *}$ & 1.00 & & & & & & \\
\hline 6. & OJT & 0.40 & 0.49 & $0.17^{* * *}$ & $0.19^{* * *}$ & $0.24^{* * *}$ & $0.21^{* * *}$ & $0.18^{* * *}$ & 1.00 & & & & & \\
\hline 7. & Edu_high & 0.09 & 0.29 & $0.11^{* * *}$ & $0.12^{* * *}$ & $0.06^{* * *}$ & $0.04^{* * *}$ & $0.13^{* * *}$ & $0.02 * *$ & 1.00 & & & & \\
\hline 8. & Univ_high & 0.34 & 0.48 & -0.01 & -0.01 & $0.02 * *$ & $0.03^{* * *}$ & 0.01 & $0.03 * * *$ & $0.06^{* * *}$ & 1.00 & & & \\
\hline 10. & Labor Force_adv & 0.73 & 0.06 & $0.02 * *$ & -0.01 & 0.00 & 0.01 & 0.00 & -0.01 & $-0.08^{* * *}$ & $-0.19^{* * *}$ & $0.13^{* * *}$ & 1.00 & \\
\hline 11. & Size & 12.76 & 7.06 & $0.09^{* * *}$ & $0.08^{* * *}$ & $0.09 * * *$ & $0.09 * * *$ & $0.10 * * *$ & $0.09^{* * *}$ & $0.04^{* * *}$ & $-0.07^{* * *}$ & $0.03^{* * *}$ & $-0.07^{* * *}$ & 1.00 \\
\hline 12. & State_ownership & 0.00 & 0.06 & 0.00 & 0.01 & 0.01 & 0.01 & $0.02 *$ & 0.01 & $0.02 *$ & -0.01 & 0.02 & -0.01 & $0.02 * *$ \\
\hline 13. & Domestic_ownership & 0.92 & 0.27 & $-0.07^{* * *}$ & $-0.04^{* * *}$ & $-0.07^{* * *}$ & $-0.05^{* * *}$ & $-0.06^{* * *}$ & $-0.09^{* * *}$ & 0.02 & $0.03^{* * *}$ & $-0.06^{* * *}$ & $-0.11^{* * *}$ & $-0.05^{* * *}$ \\
\hline 14. & Foreign_ownership & 0.05 & 0.22 & $0.07^{* * *}$ & $0.04^{* * *}$ & $0.07^{* * *}$ & $0.05^{* * *}$ & $0.07^{* * *}$ & $0.09^{* * *}$ & -0.01 & -0.02 & $0.04^{* * *}$ & $0.09^{* * *}$ & $0.06^{* * *}$ \\
\hline 15. & Log_CEO_experience & 2.59 & 0.78 & $0.09 * * *$ & $0.05^{* * *}$ & $0.05^{* * *}$ & $0.04^{* * *}$ & $0.05^{* * *}$ & $0.08^{* * *}$ & $0.04^{* * *}$ & $-0.08^{* * *}$ & $0.04^{* * *}$ & $0.07^{* * *}$ & $0.08^{* * *}$ \\
\hline 16. & CEO_female & 0.22 & 0.41 & $-0.05^{* * *}$ & $-0.03^{* * *}$ & $-0.02 * *$ & -0.01 & $-0.05^{* * *}$ & -0.01 & $-0.05^{* * *}$ & $0.02 *$ & $0.04^{* * *}$ & $0.04^{* * *}$ & $-0.05^{* * *}$ \\
\hline 17. & Log_firm age & 2.45 & 0.68 & $0.10^{* * *}$ & $0.07^{* * *}$ & $0.07^{* * *}$ & $0.07^{* * *}$ & $0.07^{* * *}$ & $0.07^{* * *}$ & $0.03^{* * *}$ & $-0.15^{* * *}$ & $0.09^{* * *}$ & $0.10^{* * *}$ & $0.11^{* * *}$ \\
\hline 18. & Corporation & 0.92 & 0.27 & 0.01 & $0.03^{* * *}$ & $0.03^{* * *}$ & $0.02 *$ & $0.05^{* * *}$ & $0.04^{* * *}$ & $0.03^{* * *}$ & $0.10^{* * *}$ & $-0.05^{* * *}$ & $-0.16^{* * *}$ & $0.06^{* * *}$ \\
\hline 20. & Capacity & 0.22 & 0.36 & $0.16^{* * *}$ & $0.17^{* * *}$ & $0.06^{* * *}$ & $0.05^{* * *}$ & $0.15^{* * *}$ & 0.01 & $0.42 * * *$ & $-0.14^{* * *}$ & 0.01 & 0.00 & $0.10^{* * *}$ \\
\hline 21. & External financing & 0.23 & 0.33 & $0.05^{* * *}$ & $0.06^{* * *}$ & $0.08^{* * *}$ & $0.08^{* * *}$ & $0.04^{* * *}$ & $0.03^{* * *}$ & $-0.02 *$ & $-0.06^{* * *}$ & -0.01 & $0.02 * *$ & $0.10^{* * *}$ \\
\hline 22. & Log_competitors & 2.52 & 1.82 & $-0.06^{* * *}$ & $-0.04^{* * *}$ & $-0.03^{* * *}$ & 0.01 & $-0.08^{* * *}$ & -0.01 & $-0.04^{* * *}$ & $0.05^{* * *}$ & -0.01 & $-0.06^{* * *}$ & $-0.03^{* * *}$ \\
\hline 23. & Sales_domestic & 0.91 & 0.24 & $-0.06^{* * *}$ & $-0.06^{* * *}$ & $-0.05^{* * *}$ & -0.01 & $-0.11^{* * *}$ & $-0.03^{* * *}$ & 0.00 & $0.12^{* * *}$ & $-0.08^{* * *}$ & $-0.17^{* * *}$ & $-0.04^{* * *}$ \\
\hline
\end{tabular}


Table 4. Cont.

\begin{tabular}{|c|c|c|c|c|c|c|c|c|c|c|c|c|c|c|c|}
\hline No. & Variable & Mean & SD & 12 & 13 & 14 & 15 & 16 & 17 & 18 & 19 & 20 & 21 & 22 & 23 \\
\hline 1. & Product_inno & 0.27 & 0.44 & & & & & & & & & & & & \\
\hline 2. & Process_inno & 0.22 & 0.42 & & & & & & & & & & & & \\
\hline 3. & Organiation_inno & 0.23 & 0.42 & & & & & & & & & & & & \\
\hline 4. & Marketing_inno & 0.25 & 0.43 & & & & & & & & & & & & \\
\hline 5. & $R \mathcal{E} D \_$spending & 0.11 & 0.32 & & & & & & & & & & & & \\
\hline 6. & OJT & 0.40 & 0.49 & & & & & & & & & & & & \\
\hline 7. & Edu_high & 0.09 & 0.29 & & & & & & & & & & & & \\
\hline 8. & Univ_high & 0.34 & 0.48 & & & & & & & & & & & & \\
\hline 9. & GDP_edu & 0.04 & 0.01 & & & & & & & & & & & & \\
\hline 10. & Labor Force_adv & 0.73 & 0.06 & & & & & & & & & & & & \\
\hline 11. & Size & 12.76 & 7.06 & & & & & & & & & & & & \\
\hline 12. & State_ownership & 0.00 & 0.06 & 1.00 & & & & & & & & & & & \\
\hline 13. & Domestic_ownership & 0.92 & 0.27 & $-0.20^{* * *}$ & 1.00 & & & & & & & & & & \\
\hline 14. & Foreign_ownership & 0.05 & 0.22 & -0.01 & $-0.79 * * *$ & 1.00 & & & & & & & & & \\
\hline 15. & Log_CEO_experience & 2.59 & 0.78 & 0.01 & $0.05^{* * *}$ & $-0.03^{* * *}$ & 1.00 & & & & & & & & \\
\hline 16. & CEO_female & 0.22 & 0.41 & -0.01 & $0.03^{* * *}$ & $-0.03^{* * *}$ & $-0.03^{* * *}$ & 1.00 & & & & & & & \\
\hline 17. & Log_firm age & 2.45 & 0.68 & $0.07^{* * *}$ & $-0.02 * *$ & -0.01 & $0.34^{* * *}$ & -0.01 & 1.00 & & & & & & \\
\hline 18. & Corporation & 0.92 & 0.27 & 0.00 & $-0.03^{* * *}$ & $0.05^{* * *}$ & $-0.04^{* * *}$ & $-0.04^{* * *}$ & $-0.11^{* * *}$ & 1.00 & & & & & \\
\hline 19. & Multiple_establishments & 0.05 & 0.21 & 0.00 & $-0.16^{* * *}$ & $0.16^{* * *}$ & $-0.05^{* * *}$ & $-0.02 *$ & -0.01 & $0.03^{* * *}$ & 1.00 & & & & \\
\hline 20. & Capacity & 0.22 & 0.36 & $0.03^{* * *}$ & $-0.04^{* * *}$ & $0.05^{* * *}$ & $0.06^{* * *}$ & $-0.07^{* * *}$ & $0.10 * * *$ & $0.03 * * *$ & 0.01 & 1.00 & & & \\
\hline 21. & External financing & 0.23 & 0.33 & $0.03^{* * *}$ & $-0.02 *$ & 0.01 & $0.05^{* * *}$ & -0.01 & $0.04^{* * *}$ & -0.01 & -0.01 & 0.01 & 1.00 & & \\
\hline 22. & Log_competitors & 2.52 & 1.82 & -0.01 & $0.12^{* * *}$ & $-0.11^{* * *}$ & 0.00 & $0.03^{* * *}$ & $-0.06^{* * *}$ & -0.01 & $-0.04^{* * *}$ & $-0.14^{* * *}$ & 0.00 & 1.00 & \\
\hline 23. & Sales_domestic & 0.91 & 0.24 & -0.01 & $0.23 * * *$ & $-0.21^{* * *}$ & 0.00 & $0.04^{* * *}$ & $-0.06^{* * *}$ & -0.01 & $-0.07^{* * *}$ & $-0.21^{* * *}$ & $-0.04^{* * *}$ & $0.31^{* * *}$ & 1.00 \\
\hline
\end{tabular}

Note: ${ }^{*} p<0.10 ;{ }^{* *} p<0.05 ; * * * p<0.01$. 


\subsection{First Stage Regression Results}

The first stage regression results are presented in Table 5. The test variable OJT has a positive and significant relation with instrumental variable GDP_edu (\% of GDP of government spending in education) but significantly negative relation with instrumental variable Labor Force_adv (\% of labor force with advanced education in total workingage population). The coefficient on GDP_edu is 4.48, whereas that on Labor Force_adv is -0.46. On the other hand, Edu_high and Univ_high are negatively associated with both instrumental variables at the $1 \%$ level. The coefficients on GDP_edu and Labor Force_adv are -8.26 and -2.84 when the dependent variable is Edu_high, while they are -14.50 and -3.74 when the dependent variable is Univ_high.

Table 5. First stage regression results (total observations $=10,366$ ).

\begin{tabular}{cccc}
\hline Dependent Variable & $(\mathbf{1})$ OJT & (2) Edu_high & (3) Univ_high \\
\hline Intercept & $-0.85^{* * *}$ & $-0.80^{*}$ & $2.86^{* * *}$ \\
GDP_edu & $4.48^{* * *}$ & $-8.26^{* * *}$ & $-14.50^{* * *}$ \\
Labor Force_adv & $-0.46^{* * *}$ & $-2.84^{* * *}$ & $-3.74^{* * *}$ \\
Size & $0.01^{* * *}$ & 0.00 & $-0.01^{* * *}$ \\
State_ownership & -0.11 & 0.46 & 0.10 \\
Domestic_ownership & $-0.21^{* * *}$ & $0.30^{*}$ & -0.01 \\
Foreign_ownership & $0.23^{* *}$ & 0.17 & 0.12 \\
log_CEO_experience & $0.11^{* * *}$ & $0.07^{* *}$ & -0.03 \\
CEO_female & $0.02^{* * *}$ & -0.08 & 0.04 \\
Log_firm age & $0.09^{* * *}$ & -0.05 & $-0.18^{* * *}$ \\
Corporation & $0.16^{* * *}$ & 0.10 & $0.36^{* * *}$ \\
Multiple_establishments & $0.57^{* * *}$ & $0.32^{* * *}$ & 0.04 \\
Capacity & $0.19^{* * *}$ & $0.57^{* * *}$ & $-0.13^{*}$ \\
External financing & $0.10^{* *}$ & -0.09 & $-0.22^{* * *}$ \\
Log_competitors & 0.00 & -0.01 & 0.00 \\
Sales_domestic & 0.01 & $0.60^{* * *}$ & $0.42^{* * *}$ \\
Industry_Dummy & Included & Included & Included \\
Pseudo R ${ }^{* *}$ & 0.0424 & 0.2047 & 0.1084 \\
\hline
\end{tabular}

Note: ${ }^{*} p<0.10 ;{ }^{* *} p<0.05 ;{ }^{* * *} p<0.01$.

\subsection{Main Regression Results}

Table 6 reports the main regression results based on test variable OJT, Edu_high, and Univ_high in Panels A, B, and C, respectively. In Panel A, test variable OJT has positive and significant relations with all innovation measures at the $1 \%$ level. The coefficients are $0.69,0.81,0.98,0.86$, and 1.00 when the dependent variable is Product_inno, Process_inno, Organization_inno, Marketing_inno, and RED_investment, respectively.

Similar to variable OJT, test variables Edu_high and Univ_high are positively and significantly associated with all innovation measures at the $1 \%$ level. When the dependent variable is Product_inno,Process_inno,Organization_inno, Marketing_inno, and RED_investment, the coefficients on Edu_high (in Panel B) are 0.34, 0.38, 0.31, 0.24, and 0.65, while those on Univ_high (in Panel C) are 0.35, 0.20, 0.27, 0.31, and 0.47, respectively. 
Table 6. Main regression results (total observations $=10,366$ ).

\begin{tabular}{|c|c|c|c|c|c|}
\hline \multicolumn{6}{|c|}{ Panel A: Test Variable $=O J T$} \\
\hline Dependent Variable & Product_inno & Process_inno & Organization_inno & Marketing_inno & RED_investment \\
\hline Intercept & 1.31 & -1.96 & -2.70 & -1.90 & $-10.33^{* *}$ \\
\hline OJT & $0.69^{* * *}$ & $0.81^{* * *}$ & $0.98^{* * *}$ & $0.86^{* * *}$ & $1.00^{* * *}$ \\
\hline Size & 0 & 0.01 & 0.02 & 0.01 & $0.07^{* * *}$ \\
\hline State_ownership & -0.43 & -0.09 & -0.12 & -0.13 & 0 \\
\hline Domestic_ownership & 0.04 & 0.03 & -0.15 & -0.11 & -0.54 \\
\hline Foreign_ownership & -0.33 & -0.04 & 0.2 & 0.06 & 0.83 * \\
\hline log_CEO_experience & -0.05 & 0 & 0.04 & -0.05 & $0.39 *$ \\
\hline CEO_female & $-0.19^{* * *}$ & -0.12 & -0.10 & -0.04 & $-0.25^{* *}$ \\
\hline Log_firm age & -0.06 & 0.11 & 0.14 & 0.1 & $0.40^{* *}$ \\
\hline Corporation & -0.11 & 0.1 & 0.2 & 0.09 & $1.19^{* * *}$ \\
\hline Multiple_establishments & -0.50 & 0.3 & 0.65 & 0.26 & $1.94 * *$ \\
\hline Capacity & -0.22 & 0.3 & 0.2 & 0 & 0.58 \\
\hline External financing & 0.1 & $0.39 * *$ & $0.56^{* * *}$ & $0.45^{* * *}$ & $0.56^{* * *}$ \\
\hline Log_competitors & $-0.06^{* * *}$ & $-0.05^{* * *}$ & -0.03 * & 0.02 & $-0.07^{* * *}$ \\
\hline Sales_domestic & 0.21 * & -0.12 & $-0.26^{* *}$ & 0.03 & $-0.46^{* * *}$ \\
\hline$\overline{I M R}$ & -2.33 & -0.40 & 0.14 & -0.28 & 4.39 \\
\hline Industry_Dummy & Included & Included & Included & Included & Included \\
\hline Pseudo $\mathrm{R}^{2}$ & 0.0978 & 0.1024 & 0.1043 & 0.0899 & 0.0853 \\
\hline \multicolumn{6}{|c|}{ Panel B: Test Variable $=E d u \_h i g h$} \\
\hline Dependent Variable & Product_inno & Process_inno & Organization_inno & Marketing_inno & RED_investment \\
\hline Intercept & -5.02 & -4.84 & $-11.53^{* * *}$ & $-10.85^{* * *}$ & $-10.40^{* *}$ \\
\hline Edu_high & $0.34^{* * *}$ & $0.38^{* * *}$ & $0.31^{* * *}$ & $0.24^{* * *}$ & $0.65^{* * *}$ \\
\hline Size & $0.02^{* * * *}$ & $0.01 * *$ & $0.01 * *$ & $0.01 * *$ & $0.03^{* * *}$ \\
\hline State_ownership & -0.31 & 0.09 & 0.87 & 0.8 & 1 \\
\hline Domestic_ownership & -0.13 & 0.07 & 0.46 & 0.43 & 0.48 \\
\hline Foreign_ownership & 0.16 & 0.16 & $0.64^{* * *}$ & $0.54^{* *}$ & 0.57 * \\
\hline log_CEO_experience & $0.20^{* * *}$ & 0.1 & $0.22^{* * *}$ & $0.14^{* *}$ & $0.18^{* *}$ \\
\hline CEO_female & $-0.21 * *$ & $-0.16^{*}$ & $-0.28^{* * *}$ & $-0.21 * *$ & $-0.44^{* * *}$ \\
\hline Log_firm age & 0.08 & $0.14^{* *}$ & 0.06 & 0.04 & 0.09 \\
\hline Corporation & $0.26^{* *}$ & 0.24 * & $0.46^{* * *}$ & $0.37^{* * *}$ & $0.91^{* * *}$ \\
\hline
\end{tabular}


Table 6. Cont.

\begin{tabular}{|c|c|c|c|c|c|}
\hline \multicolumn{6}{|c|}{ Panel B: Test Variable $=E d u \_h i g h$} \\
\hline Dependent Variable & Product_inno & Process_inno & Organization_inno & Marketing_inno & $R \mathcal{E D}$ _investment \\
\hline Multiple_establishments & $0.69^{* * *}$ & $0.77^{* * *}$ & $1.48^{* * *}$ & $1.19 * * *$ & $1.09^{* * *}$ \\
\hline Capacity & 0.45 & 0.63 & $1.32 * * *$ & $1.12 * *$ & 0.81 \\
\hline External financing & $0.22 * *$ & $0.39^{* * *}$ & $0.37^{* * *}$ & $0.30^{* * *}$ & 0.15 \\
\hline Log_competitors & $-0.06^{* * *}$ & $-0.05^{* * *}$ & $-0.05^{* * *}$ & 0 & $-0.09 * * *$ \\
\hline Sales_domestic & 0.6 & 0.19 & $1.02 * *$ & $1.22 * *$ & 0.41 \\
\hline$\overline{I M R}$ & 0.86 & 0.71 & $2.63^{* * *}$ & $2.48^{* * *}$ & 1.95 \\
\hline Industry_Dummy & Included & Included & Included & Included & Included \\
\hline Country_Dummy & Included & Included & Included & Included & Included \\
\hline Pseudo $R^{2}$ & 0.0819 & 0.083 & 0.0732 & 0.0638 & 0.0699 \\
\hline \multicolumn{6}{|c|}{ Panel C: Test Variable = Univ_high } \\
\hline Dependent Variable & Product_inno & Process_inno & Organization_inno & Marketing_inno & RED_investment \\
\hline Intercept & $3.36^{*}$ & 0.07 & 0.01 & 2.24 & 0.21 \\
\hline Univ_high & $0.35^{* * *}$ & $0.20 * * *$ & $0.27 * * *$ & $0.31 * * *$ & $0.47^{* * *}$ \\
\hline Size & $0.05^{* * *}$ & $0.03^{* * *}$ & $0.03^{* * *}$ & $0.04^{* * *}$ & $0.06^{* * *}$ \\
\hline State_ownership & $-0.94 * *$ & -0.31 & -0.28 & -0.42 & 0.08 \\
\hline Foreign_ownership & $-0.40 *$ & -0.14 & 0.04 & -0.20 & -0.03 \\
\hline log_CEO_experience & $0.24^{* * *}$ & $0.10^{* *}$ & $0.11^{* *}$ & $0.07^{*}$ & $0.15^{* *}$ \\
\hline CEO_female & $-0.28^{* * *}$ & $-0.17^{* *}$ & $-0.15^{* *}$ & -0.14 * & $-0.41^{* * *}$ \\
\hline Log_firm age & $0.67^{* * *}$ & $0.42 * *$ & $0.41^{* *}$ & $0.59 * * *$ & $0.58^{* *}$ \\
\hline Corporation & $-1.04^{* * *}$ & -0.39 & -0.32 & $-0.84^{* *}$ & -0.19 \\
\hline Multiple_establishments & $0.33^{* * *}$ & $0.54^{* * *}$ & $0.73^{* * *}$ & $0.43^{* * *}$ & $0.51^{* * *}$ \\
\hline Capacity & $0.56^{* * *}$ & $0.58^{* * *}$ & $0.41^{* *}$ & $0.43^{* *}$ & 0.38 \\
\hline External financing & $0.97^{* * *}$ & $0.76^{* * *}$ & $0.87^{* * *}$ & $1.04^{* * *}$ & $0.80 * *$ \\
\hline Log_competitors & $-0.07^{* * *}$ & $-0.05^{* * *}$ & $-0.03^{* *}$ & 0.01 & $-0.09^{* * *}$ \\
\hline Sales_domestic & $-1.21^{* *}$ & -0.77 & $-0.87^{*}$ & $-1.12^{* *}$ & $-1.52^{* *}$ \\
\hline$I M R$ & $-4.26^{* * *}$ & -1.94 & -1.84 & $-3.46^{* *}$ & -3.09 \\
\hline Industry_Dummy & Included & Included & Included & Included & Included \\
\hline Country_Dummy & Included & Included & Included & Included & Included \\
\hline Pseudo $R^{2}$ & 0.0845 & 0.0823 & 0.0734 & 0.0656 & 0.0693 \\
\hline
\end{tabular}




\subsection{Robustness Tests Results}

As an additional analysis, Edu_high and Univ_high are replaced as Edu_high1 (which are equal to 1 if average number of years of education of typical production worker is equal to or greater than the median value (12 years), and 0 otherwise) and Univ_high1 (which is equal to 1 if \% of permanent full-time workers with a university degree is equal to or greater than median value $(27 \%)$, and 0 otherwise), in the main regressions. The results based on Edu_high1 and Univ_high1 are qualitatively the same as the main results. In addition, all the results remain qualitatively the same when using the number of employees as a control for firm size (i.e., dummies for size: micro, small, medium, large).

\section{Discussion and Conclusions}

This study aims to test the effects of human capital, specifically the education level of employees and on-the-job training, on the innovativeness of firms in emerging markets. While the term 'innovation' has been traditionally associated with the introduction of new product or technology, it now includes other items, such as new production processes, organizational structure, and marketing (Atalay et al. [3]). Based on this definition, this study investigates five types of innovation activities-product, process, marketing, organizational innovation, and R\&D investment. The research question is addressed by using a sample of 10,366 firms from BEEPS 2013 (Business Environment and Enterprise Performance Survey 2013).

Our findings are as follows. Firstly, on-the-job-training is positively and significantly associated with all five indicators of firms' innovation, suggesting that on-the-job-training can increase innovation, consistent with previous literature on other markets. Secondly, more than 12 years of education of employees has a significant and positive relation with all five types of firms' innovation, implying that quantity of education can affect innovation of firms. Finally, the indicator for more than $50 \%$ of employees having university degrees is significantly and positively related with all five types of innovation, which suggests that the quality of education is also important to promote innovation.

The results seem to agree with the intuition that innovativeness increases with better educated (and therefore more knowledgeable) workforce and proper training. However, the results regarding product innovation partially disagree with the results from Nazarov and Akhmedjonov [13], who find that only on-the-job training has a significant impact on product innovation. This difference may be explained by the change in economic circumstances. Nazarov and Akhmedjonov [13] argue that innovation in transition economies mainly occurs through the adoption, rather than invention, of new products and technology. Unlike invention, adoption of technology relies on workers with technical skills, with specific training provided when necessary. However, there is only so much innovation that can occur through adoption-at some point, the focus needs to shift to invention. The change in significance for product innovation may have occurred because of this shift.

The significant and positive relation for other forms of innovation may be explained by the skills required for these forms. Just as inventing new technology would require knowledge beyond that provided by secondary education, other forms of innovationprocess, organizational, and marketing - seem to be based on post-secondary education. For example, process or organizational innovation may require an industrial engineering degree since the program often relates to process optimization, while marketing innovation may require an MBA(Master of Business Administration) degree. While on-the-job training may provide the same knowledge, having the base knowledge from the beginning can also contribute to innovation.

By testing the effectiveness of higher education of employees and on-the-job training on firm innovation, this paper makes the following contributions to the existing literature on innovation in emerging markets. Firstly, this study provides empirical evidence on an updated relationship between education level, on-the-job training, and an expanded set of innovation indicators using the most up-to-date dataset. Secondly, findings of this study can convey insightful implications by providing useful information on the 
effectiveness of education and on-the-job training on innovativeness of firms in emerging markets, especially for policymakers. When education did not have a significant effect on innovation, investing in higher education may have been suboptimal compared to investing in worker training programs. However, with the new results, it may be worth considering redistributing the investments to education in order to promote innovation. Similarly, this study may give useful suggestions for practitioners in emerging markets by emphasizing both higher level of education, especially university level education and the number of years of education, in the workforce and on-the-job training. It would be worthwhile for firms to start or continue to provide appropriate training programs to its employees, while human resource managers may want to invest in sifting through potential hires for those with higher education in order to promote innovation at firm level.

Although this paper provides important evidence to the current literature, it uses firms in Eastern Europe and Central Asia region, which may restrict its applications to other emerging markets. Thus, it would be worthwhile to extend this research to other emerging markets in other regions.

Funding: This research received no external funding.

Data Availability Statement: Data available in a publicly accessible repository that does not issue DOIs. Publicly available datasets were analyzed in this study. This data can be found here: [https:// login.enterprisesurveys.org/content/sites/financeandprivatesector/en/library/library-detail.html/ content/dam/wbgassetshare/enterprisesurveys/combineddata/eastern-europe-central-asia/BEEPS2 013_comprehensive_external-portal-final.zip].

Conflicts of Interest: The author declares no conflict of interest.

\section{References}

1. Beaver, G. Small Business, Entrepreneurship and Enterprise Development; Pearson Education: London, UK, 2002.

2. Dawar, N.; Frost, T. Competing with Giants: Survival Strategies for Local Companies in Emerging Markets. Harv. Bus. Rev. 1999, 77, 119-129.

3. Atalay, M.; Anafarta, N.; Sarvan, F. The relationship between innovation and firm performance: An empirical evidence from Turkish automotive supplier industry. Procedia Soc. Behav. Sci. 2013, 75, 226-235. [CrossRef]

4. Ayyagari, M.; Demirgüç-Kunt, A.; Maksimovic, V. Firm innovation in emerging markets: The role of finance, governance, and competition. J. Financ. Quant. Anal. 2011, 46, 1545-1580. [CrossRef]

5. Gorodnichenko, Y.; Svejnar, J.; Terrell, K. Globalization and innovation in emerging markets. Am. Econ. J. Macroecon. 2010, 2, 194-226. [CrossRef]

6. Zhou, K.Z.; Yong, G.Z.; Zhao, H. State ownership and firm innovation in China: An integrated view of institutional and efficiency logics. Admin. Sci. Quart. 2017, 62, 375-404. [CrossRef]

7. Mahmood, I.P.; Mitchell, W. Two faces: Effects of business groups on innovation in emerging economies. Manag. Sci. 2004, 50, 1348-1365. [CrossRef]

8. Arvanitis, S.; Stucki, T. What determines the innovation capability of firm founders? Ind. Corp. Chang. 2012, 21, 1049-1084. [CrossRef]

9. Marvel, M.R.; Lumpin, G.T. Technology Entrepreneurs Human Capital and its Effects on Innovation Radicalness. Entrep. Theory Pract. 2007, 31, 807-828. [CrossRef]

10. Abdullah, N.H.; Ping, L.L.; Wahab, E.; Shamsuddin, A. Perception on Training and Employee Innovativeness: An Evidence from Small Firms. In Proceedings of the 2014 IEEE International Conference on Management of Innovation and Technology, Singapore, 23-25 September 2014; pp. 76-80.

11. Bauernschuster, S.; Falck, O.; Heblich, S. Training and Innovation. J. Hum. Cap. 2009, 3, 323-353. [CrossRef]

12. Gonzalez, X.; Miles-Touya, D.; Pazo, C. R\&D, worker training and innovation: Firm-level evidence. Ind. Innov. 2016, 23, 694-712.

13. Nazarov, Z.; Akhmedjonov, A. Education, On-the-Job Training, and Innovation in Transition Economies. East. Eur. Econ. 2012, 50, 28-56. [CrossRef]

14. Enterprise Surveys Portal Datasets-World Bank Group. Available online: https://www.enterprisesurveys.org/en/surveydatasets (accessed on 1 January 2021).

15. Fact Sheet-Eastern Europe and Central Asia. Available online: https://www.doingbusiness.org/en/media/fact-sheets/2011 / eca (accessed on 1 January 2021).

16. Heckman, J. Sample selection bias as a specification error. Econometrica 1979, 47, 153-161. [CrossRef]

17. Beaver, G.; Jennings, P. Editorial overview: Small business, entrepreneurship and enterprise development. Strateg. Chang. 2000, 9 , 397-403. [CrossRef] 
18. Bourke, J.; Crowley, F. The Influence of the Manager on Firm Innovation in Emerging Economies. Int. J. Innov. Manag. 2018, 22, 1-21.

19. Romer, P.M. Endogenous technological change. J. Political Econ. 1990, 98, S71-S102. [CrossRef]

20. Schroeder, R.; Van de Ven, A.; Scudder, G.; Polley, D. Managing Innovation and Change Processes: Findings from the Minnesota Innovation Research Program. Agribusiness 1986, 2, 501-523. [CrossRef]

21. Danneels, E. The dynamics of product innovation and firm competences. Strateg. Manag. J. 2002, 23, 1095-1121. [CrossRef]

22. Hult, G.; Tomas, M.; Hurley, R.F.; Knight, G.A. Innovativeness: Its antecedents and impact on business performance. Ind. Mark. Manag. 2004, 33, 429-438. [CrossRef]

23. Kleinschmidt, E.J.; Cooper, R.G. The Impact of Product Innovativeness on Performance. J. Prod. Innov. Manag. 1991, 8, $240-251$. [CrossRef]

24. Camison, C.; López, A.V. An examination of the relationship between manufacturing flexibility and firm performance: The mediating role of innovation. Int. J. Oper. Prod. Manag. 2010, 30, 853-878. [CrossRef]

25. Varis, M.; Littunen, H. Types of innovation, sources of information and performance in entrepreneurial SMEs. Eur. J. Innov. Manag. 2010, 13, 128-154. [CrossRef]

26. Ar, I.M.; Baki, B. Antecedents and performance impacts of product versus process innovation: Empirical evidence from SMEs located in Turkish science and technology parks. Eur. J. Innov. Manag. 2011, 14, 172-206.

27. Morone, P.; Testa, G. Firms growth, size and innovation an investigation into the Italian manufacturing sector. Econ. Innov. New Technol. 2008, 17, 311-329. [CrossRef]

28. Vivero, R.L. The impact of process innovations on firm's productivity growth: The case of Spain. Appl. Econ. 2002, 34, 1007-1016. [CrossRef]

29. Rosenberg, N.; Nathan, R. Inside the Black Box: Technology and Economics; Cambridge University Press: Cambridge, UK, 1982.

30. Diaz-Fernandez, M.; Bornay-Barrachina, M.; Lopez-Cabrales, A. Innovation and firm performance: The role of human resource management practices. Evid. Based Hrm. Glob. Forum Empir. Scholarsh. 2015, 3, 64-80. [CrossRef]

31. Laplagne, P.; Bensted, L. The Role of Training and Innovation in Workplace Performance. Productivity Commission Working Paper No. 1609. 1999. Available online: https:/ / papers.ssrn.com/sol3/papers.cfm?abstract_id=324760 (accessed on 10 January 2021).

32. Krishnan, R.; Jha, S. Innovation Strategies in Emerging Markets: What Can We Learn from Indian Market Leaders. ASCI J. Manag. 2011, 41, 21-45.

33. Hu, X.; Danso, B.; Adjei Mensah, I.; Addai, M. Does Innovation Type Influence Firm Performance? A Dilemma of Star-Rated Hotels in Ghana. Sustainability 2020, 12, 9912. [CrossRef]

34. Kurt, S.; Kurt, Ü. Innovation and labour productivity in BRICS countries: Panel causality and co-integration. Procedia Soc. Behav. Sci. 2015, 195, 1295-1302. [CrossRef]

35. Rajapathirana, R.P.; Hui, Y. Relationship between innovation capability, innovation type, and firm performance. J. Innov. Knowl. 2018, 3, 44-55. [CrossRef]

36. Lynch, R.; Jin, Z. Knowledge and innovation in emerging market multinationals: The expansion paradox. J. Bus. Res. 2015, 69, 1593-1597. [CrossRef]

37. McGrath, R.G.; MacMillan, I.; Venkataraman, S. Defining and developing competence: A strategic process paradigm. Strateg. Manag. J. 1995, 16, 251-275. [CrossRef]

38. Cho, H.; Pucik, V. Relationship between innovativeness, quality, growth, profitability, and market value. Strateg. Manag. J. 2005, 26, 555-570. [CrossRef]

39. Santamaría, L.; Nieto, M.; Barge-Gil, A. Beyond Formal R\&D: Taking Advantage of Other Sources of Innovation in Low and Medium Technology Industries. Res. Policy 2009, 38, 507-517.

40. Reuvers, M.; Van Engen, M.L.; Vinkenburg, C.J.; Wilson-Evered, E. Transformational Leadership and Innovative Work Behaviour: Exploring the Relevance of Gender Differences. Creat. Innov. Manag. 2008, 17, 227-244. [CrossRef]

41. Yun, J.; Liu, Z. Micro- and Macro-Dynamics of Open Innovation with a Quadruple-Helix Model. Sustainability 2019, $11,3301$. [CrossRef]

42. Yun, J.J.; Nadhiroh, I.M.; Jung, W.Y. The relationship between open innovation, entrepreneurship, and introduction of new business models in Korean and Indonesian information technology enterprises. Korean Soc. Sci. J. 2013, 40, 81-99. [CrossRef]

43. Yun, J.; Zhao, X.; Jung, K.; Yigitcanlar, T. The Culture for Open Innovation Dynamics. Sustainability 2020, 12, 5076. [CrossRef]

44. Wang, C.; Kafouros, M.I. What factors determine innovation performance in emerging economies? Evidence from China. Int. Bus. Rev. 2009, 18, 606-616. [CrossRef]

45. Reichstein, T.; Salter, A. Investigating the sources of process innovation among UK manufacturing firms. Ind. Corp. Chang. 2006, 15, 653-682. [CrossRef]

46. Schøtt, T.; Cheraghi, M. Gendering pursuits of innovation: Embeddedness in networks and culture. Int. J. Entrep. Small Bus. 2015, 24, 83-116. [CrossRef]

47. Ayub, A.; Razzaq, A.; Aslam, M.S.; Iftekhar, H. Gender effects on entrepreneurial orientation and value innovation: Evidence from Pakistan. Eur. J. Bus. Soc. Sci. 2013, 2, 82-90.

48. Mueller, S.L. Gender gaps in potential for entrepreneurship across countries and cultures. J. Dev. Entrep. 2004, 9, 199-220.

49. Chen, J.; Leung, W.S.; Evans, K. Female board representation, corporate innovation and firm Performance. J. Empir. Financ. 2018, 48, 236-254. [CrossRef] 
50. Na, K.; Shin, K. The Gender Effect on a Firm's Innovative Activities in the Emerging Economies. Sustainability $2019,11,1992$. [CrossRef]

51. Turner, L. Gender diversity and innovative performance. Int. J. Innov. Sustain. Dev. 2009, 4, 123-134. [CrossRef]

52. Østergaard, C.R.; Timmermans, B.; Kristinsson, K. Does a different view create something new? The effect of employee diversity on innovation. Res. Policy 2011, 40, 500-509. [CrossRef]

53. Galia, F.; Zenou, E.; Ingham, M. Board composition and environmental innovation: Does gender diversity matter? Int. J. Entrep. Small Bus. 2015, 24, 117-141. [CrossRef]

54. Chang, S.J.; Chung, C.N.; Mahmood, I.P. When and how does business group affiliation promote firm innovation? A tale of two emerging economies. Organ. Sci. 2006, 17, 637-656. [CrossRef]

55. Li, C. Enhancing or inhibiting: The impact of investment in political ties on the link between firm innovation and productivity. Int. Bus. Rev. 2020, 29, 101636. [CrossRef]

56. Kushnirovich, N.; Heilbrunn, S. Innovation and conformity: Intersection of gender and ethnicity in hi-tech organizations. J. Manag. Dev. 2013, 32, 204-220. [CrossRef]

57. Ozgen, C.; Nijkamp, P.; Poot, J. Measuring Cultural Diversity and its Impact on Innovation: Longitudinal Evidence from Dutch Firms. IZA Discussion Paper No. 7129. Available online: https:/ / ssrn.com/abstract=2203279 (accessed on 11 January 2021).

58. Barney, J. Firm resources and sustained competitive advantage. J. Manag. 1991, 17, 99-120. [CrossRef]

59. Andries, P.; Czarnitzki, D. Small firm innovation performance and employee involvement. Small Bus. Econ. 2014, 43, 21-38. [CrossRef]

60. Børing, P. The relationship between training and innovation activities in enterprises. Int. J. Train. Dev. 2017, 21, 113-129. [CrossRef]

61. Gallié, E.P.; Legros, D. Firms' human capital, R\&D and innovation: A study on French firms. Empir. Econ. 2012, 43, 581-596.

62. Goedhuys, M. Learning, product innovation, and firm heterogeneity in developing countries; Evidence from Tanzania. Ind. Corp. Chang. 2007, 16, 269-292. [CrossRef]

63. Khatiwada, S.; Arao, R.M. Human Capital and Innovation at the Firm-Level. Asian Development Bank Background Paper. 2020. Available online: https://www.adb.org/sites/default/files/institutional-document/575671/ado2020bp-human-capitalinnovation-firm-level.pdf (accessed on 12 January 2021).

64. De Winne, S.; Sels, L. Interrelationships between human capital, HRM and innovation in Belgian start-ups aiming at an innovation strategy. Int. J. Hum. Resour. Manag. 2010, 21, 1863-1883. [CrossRef]

65. D'Amore, R.; Iorio, R.; Lubrano Lavadera, G. Exploring the Relationship between Human Capital and Innovation at the Firm Level: A Study on a Sample of European Firms (No. 144). CELPE-Centre of Labour Economics and Economic Policy; University of Salerno: Fisciano, Italy, 2017.

66. Zhang, S.; Yang, D.; Qiu, S.; Bao, X.; Li, J. Open innovation and firm performance: Evidence from the Chinese mechanical manufacturing industry. J. Eng. Technol. Manag. 2018, 48, 76-86. [CrossRef]

67. Pan, X.; Gao, Y.; Guo, D.; Cheng, W. Does Higher Education Promote Firm Innovation in China? Sustainability 2020, $12,7326$. [CrossRef]

68. van Uden, A.; Knoben, J.; Vermeulen, P. Human capital and innovation in Sub-Saharan countries: A firm-level study. Innovation 2017, 19, 103-124. [CrossRef]

69. The EBRD's Economic Surveys. Available online: https://www.ebrd.com/what-we-do/economic-research-and-data/data.html (accessed on 1 January 2021).

70. World Development Indicators I DataBank. Available online: https://databank.worldbank.org/source/world-developmentindicators (accessed on 1 January 2021).

71. Li, F. Endogeneity in CEO power: A survey and experiment. Invest. Anal. J. 2016, 45, 149-162. [CrossRef]

72. Chaney, P.K.; Jeter, D.C.; Shivakumar, L. Self-selection of auditors and audit pricing in private firms. Account. Rev. 2004, 79, 51-72. [CrossRef]

73. Na, K.; Hong, J.Y. CEO Gender and Earnings Management. J. Appl. Bus. Res. 2017, 33, 297-308. [CrossRef]

74. Petersen, M.A. Estimating standard errors in finance panel data sets: Comparing approaches. Rev. Financ. Stud. 2009, 22, 435-480. [CrossRef]

75. Dang, C.D.; Li, F.; Yang, C. Measuring Firm Size in Empirical Corporate Finance. J. Bank. Financ. 2018, 86, 159-176. [CrossRef]

76. Coles, J.; Li, F. An Empirical Assessment of Empirical Corporate Finance. SSRN Electron. J. 2016. [CrossRef]

77. Coles, J.; Li, F. Managerial Attributes, Incentives, and Performance. Rev. Corp. Financ. Stud. 2020, 9, $256-301$. 